\title{
Respons Tanaman Bawang Merah Terhadap Pemberian Pupuk Organik Cair Air Kelapa dan Mikroorganisme Lokal Bonggol Pisang
}

\author{
Khalida Firda Zanatia ${ }^{1}$, Cecep Hidayat ${ }^{2}$, dan Esty Puri Utami ${ }^{3}$ \\ 1.2.3 Jurusan Agroteknologi, Fakultas Sains dan Teknologi, \\ UIN Sunan Gunung Djati Bandung \\ JI. A. H. Nasution No. 105, Bandung, Jawa Barat 40614 \\ 1Email: khalidafirda@gmail.com
}

*Penulis korespondensi: khalidafirda@gmail.com

\begin{abstract}
Shallot (Allium ascalonicum L.) is a spice plant that is important for the people of Indonesia. Coconut water and banana weevils are expected to be used as an alternative to increase the production of shallot plants. This study aims to determine the response of shallot plants to the provision of coconut water and banana hump mole. This research was conducted from March to May 2020 in Padasuka, Bandung, West Java 653'14.5104" SL and 107³9'13.0572"EL with an altitude of 722 masl. This research was conducted using an experimental design in the form of a 2 factorial randomized block design (RBD) with 3 replications. The first factor is coconut water which consists of 4 levels ( $a_{0}=$ control, $a_{1}=25 \%, a_{2}=$ $50 \%$, and $\left.a_{3}=75 \%\right)$. The second factor was banana weevil moles which consisted of 3 levels of treatment $\left(m_{0}=\right.$ control, $m_{1}=40 \mathrm{~mL}_{\text {plant }}{ }^{1}, m_{2}=80 \mathrm{~mL}$ plant $\left.^{1}\right)$. The follow-up test used was the 5\% DMRT test (Duncan's multiple range test). The results showed that there was an interaction between coconut water and banana hump mole on plant height at 3 weeks after planting and 4 weeks after planting, but did not have an effect independently or interaction on plant height after 4 weeks after planting, number of leaves, number of tillers, and number of tubers until the end observation. It is necessary to pay attention to the storage time of banana weevil liquid organic fertilizer because it can affect the nutrients in it.
\end{abstract}

Keywords: Banana Hump Mole, Coconut Water, Liquid Organic Fertilizer, Organic, Shallots

\begin{abstract}
ABSTRAK
Bawang merah (Allium ascalonicum L.) adalah tanaman rempah yang penting bagi masyarakat Indonesia. Air kelapa dan bonggol pisang diharapkan mampu dijadikan alternatif untuk meningkatkan produksi tanaman bawang merah. Penelitian ini bertujuan untuk mengetahui respon tanaman bawang merah terhadap pemberian air kelapa dan MOL bonggol pisang. Penelitian ini dilaksanakan pada bulan Maret sampai dengan Mei 2020 di Padasuka, Bandung, Jawa Barat 6 ${ }^{\circ} 53^{\prime} 14.5104^{\prime \prime}$ LS dan $107^{\circ} 39^{\prime} 13.0572$ " BT dengan ketinggian tempat 722 mdpl. Penelitian ini dilaksanakan dengan menggunakan rancangan percobaan berupa Rancangan Acak Kelompok (RAK) 2 Faktorial dengan 3 kali ulangan. Faktor pertama adalah air kelapa yang terdiri dari 4 taraf $\left(a_{0}=\right.$ kontrol, $a_{1}=25 \%, a_{2}$ $=50 \%$, dan $\mathrm{a}_{3}=75 \%$ ). Faktor kedua adalah $\mathrm{MOL}$ bonggol pisang yang terdiri dari 3 taraf perlakuan $\left(m_{0}=\right.$ kontrol, $m_{1}=40 \mathrm{~mL}$ tanaman ${ }^{-1}, \mathrm{~m}_{2}=80 \mathrm{~mL}$ tanaman $\left.^{-1}\right)$. Uji lanjut yang digunakan adalah uji DMRT 5\% (Duncan's multiple range test). Hasil penelitian menunjukkan terjadi interaksi antara air kelapa dan MOL bonggol pisang terhadap tinggi tanaman usia $3 \mathrm{MST}$ dan $4 \mathrm{MST}$, namun tidak memberikan
\end{abstract}


pengaruh secara mandiri atau interaksi terhadap tinggi tanaman setelah $4 \mathrm{MST}$, jumlah daun, jumlah anakan, dan jumlah umbi hingga akhir pengamatan. Perlu memperhatikan waktu penyimpanan Pupuk Organik Cair (POC) MOL bonggol pisang karena dapat mempengaruhi unsur hara didalamnya.

Kata kunci: Air Kelapa, Bawang Merah, MOL Bonggol Pisang, Pupuk Organik Cair, Organik

\section{Pendahuluan}

Bawang merah (Allium ascalonicum L.) merupakan tanaman hortikultura yang penting untuk masyarakat Indonesia. Menurut Siburian \& Luthfi (2019) bawang merah adalah komoditas sayuran yang menjadi komoditas unggulan pada tingkat nasional dan sudah lama dijadikan salah satu budidaya tanaman hortikultura yang diusahkan secara intensif oleh petani. Komoditas bawang merah dikategorikan ke dalam kelompok rempah yang tidak dapat tergantikan karena dimanfaatkan untuk bahan bumbu dapur utama dan obat tradisional.

Berdasarkan Pusat Data dan Sistem Informasi Pertanian (2018) pada tahun 2013 hingga 2017 data statistik menunjukkan adanya penurunan terhadap produktivitas tanaman bawang merah yaitu dari 10,22 $\mathrm{t} \mathrm{ha}^{-1}, 10,22 \mathrm{t} \mathrm{ha}{ }^{-1}, 10,06 \mathrm{t} \mathrm{ha}^{-1}, 9,67 \mathrm{t} \mathrm{ha}^{-1}$ dan 9,29 t ha-1 secara berurutan, sedangkan Simatupang et al., (2017) menyatakan bahwa jumlah kebutuhan untuk bawang merah meningkat sejalan dengan meningkatnya pertambahan jumlah penduduk Indonesia. Hal ini dikhawatirkan akan memberikan dampak pada hasil produksi bawang merah di Indonesia pada tahun berikutnya. Oleh karena itu peningkatan produktivitas perlu dilakukan agar kebutuhan bawang merah tetap terjaga pada masa yang akan datang.

Peningkatan produktivitas dapat dilakukan dengan memperhatikan pemupukan. Berdasarkan bentuknya pupuk ada dua macam diantaranya adalah pupuk padat dan pupuk cair. Kelemahan pupuk padat adalah sifatnya slow release atau sukar untuk diurai dan membutuhkan waktu lebih lama. Menurut Duaja (2012) penggunaan pupuk organik cair belakangan ini banyak digunakan dan diminati karena mempunyai beberapa kelebihan apabila dibandingkan dengan pupuk organik padat karena sifatnya yang mudah tersedia, dan tidak merusak baik tanah atau pun tanaman. Menurut Triyanto \& Maharani (2019) nutrisi yang ada dalam Pupuk Organik Cair (POC) akan lebih mudah terserap oleh tanaman, selain itu pupuk ini lebih efektif dan efisien apabila pengaplikasiannya dilakukan pada daun, bunga, dan batang dibandingkan dengan pengaplikasian pada tanah. Peran lainnya adalah sebagai perangsang tumbuh, tertutama saat tanaman sudah memasuki masa peralihan fase vegetatif ke fase generatif.

Pupuk organik cair dapat diperoleh dari bahan organik di alam yaitu diantarannya dari air kelapa dan bagian dari pohon pisang yaitu bonggol pisang yang diolah. Air kelapa banyak dimanfaatkan baik dalam perbanyakan tanaman secara vegetatif dan generatif 
karena memiliki kandungan hara seperti protein, lemak, dan karohidrat serta auksin, sitokinin, dan giberelin yang merupakan Zat Pengatur Tumbuh (ZPT) agar dapat membantu perkembangan sel (Nizar, 2018). Pada perbanyakan tanaman, air kelapa dapat meningkatkan perfoma tanaman untuk tumbuh. Hal ini dapat terjadi karena, adanya penambahan karbohidrat yaitu gula, sehingga cadangan makanan yang bisa dirombak menjadi sumber energi dalam pertumbuhan (Napitupulu et al., 2018). Penggunaan Air Kelapa sebagai pupuk organik cair banyak digunakan dalam perbanyakan tanaman baik secara generatif atau pun vegetatif. Hal tersebut dikarenakan di dalamnya memiliki banyak kandungan seperti hara N, P, K, Na, Fe, Ca, S, B, Mg, dan Cu serta ZPT alami seperti auksin, giberelin dan sitokinin $5,8 \mathrm{mg} \mathrm{L}^{-1}$ yang berguna dalam sel tanaman untuk membantu pertumbuhan dan perkembangan (Ardi et al., 2018).

Pupuk organik cair dengan menggunakan MOL bonggol pisang dianggap penting pada fase awal pertumbuhan karena memiliki kandungan hara yang banyak di dalamnya. Pada fase awal pertumbuhan tanaman membutuhkan nutrisi dalam jumlah yang cukup besar, maka proses fisiologis seperti fotosintesis, serta mempercepat proses pemanjangan sel sehingga beberapa organ tanaman akan tumbuh secara cepat pula (Roeswitawati \& Huda, 2018). MOL bonggol pisang juga mengandung beberapa mikroorganisme seperti Bacillus sp., Aspergillus nigger, Azospirillium, Aeromonas sp., dan Azotobacter yang dapat memberikan dampak yang baik untuk pertumbuhan tanaman. Mikroba tersebut berperan dalam penguraian atau dekomposer bahan organik yang ada, baik dalam pupuk organik atau juga tanah (Budiyani et al., 2016). Selain mengurai bahan organik, MOL bonggol pisang dapat digunakan untuk merangsang pertumbuhan, dan mengendalikan hama serta penyakit tanaman (Roeswitawati et al., 2018).

Penelitian kali ini bertujuan untuk mengetahui pemanfaataan air kelapa dan MOL bonggol pisang yang dimana keduanya memiliki kandungan hara dan juga zat pengatur tumbuh alami untuk dapat membantu dalam mempengaruhi aktifitas fisiologis tanaman serta pengaruhnya terhadap tanaman bawang merah.

\section{Metode Penelitian \\ Waktu dan Tempat}

Penelitian dilakukan di Kelurahan Padasuka, Kota Bandung 653'14.5104" LS dan $107^{\circ} 39^{\prime} 13.0572$ " BT dengan ketinggian tempat 722 meter di atas permukaan laut dengan suhu berkisar $23^{\circ}-28^{\circ} \mathrm{C}$. Waktu penelitian dilaksanakan awal bulan Maret-Mei 2020.

\section{Cara Kerja}

Pembuatan larutan kelapa dilakukan dengan cara melarutkan air kelapa muda sesuai dengan konsentrasi. Konsentrasi 25\% (250 mL air kelapa $+750 \mathrm{~mL}$ air), konsentrasi 50\% (500 mL air kelapa + $50 \mathrm{~mL}$ air), dan konsentrasi $75 \%$ (750 mL air 
kelapa $+250 \mathrm{~mL}$ air). Aplikasi air kelapa dilakukan dengan cara membersihkan kulit luar umbi kemudian dipotong $1 / 4$ bagian ujungnya dan kemudian direndam dengan berbagai macam konsentrasi selama 60 menit (Ramadhani et al., 2019). Sesudah itu umbi disimpan diatas kertas untuk dikering anginkan selama \pm 10 menit sebelum ditanam.

Larutan MOL bonggol pisang dibuat dengan cara menghaluskan $1 \mathrm{~kg}$ bonggol pisang ambon, kemudian dilarutkan dengan 200 gram gula merah yang dihaluskan serta 2 liter air cucian beras dan larutan EM4 sebanyak $20 \mathrm{~mL}$, setelah itu difermentasi selama 4 - 7 hari, wadah ditutup rapat dan sesekali tutupnya dibuka pada pagi hari dengan tujuan untuk menyebabkan proses aerasi tetap berjalan (Triyanto \& Maharani, 2019). Pemberian MOL bonggol pisang dengan dosis yang sudah ditentukan, kemudian dilarutkan dengan cara melarutkannya dengan rasio $100 \mathrm{~mL}$ MOL:1.000 mL air (Aini et al., 2017). Pemberian MOL dilakukan pada saat tanaman umur 2-7 MST selama satu kali seminggu dengan membagi rata larutan MOL, pengaplikasian dilakukan langsung ke media tanam.

\section{Metode Pengolahan dan Analisis Data}

Penelitian ini menggunakan Rancangan Acak kelompok Faktorial 2 faktor yaitu Air Kelapa (a) 4 taraf dan pupuk MOL Bonggol Pisang (m) 3 taraf dengan 3 kali ulangan. Faktor pertama Air Kelapa terdiri dari 4 taraf perlakuan, yaitu: $\mathrm{a}_{0}=$ kontrol $\mathrm{a}_{1}=$ air kelapa konsentrasi $25 \% \mathrm{a}_{2}=$ air kelapa konsentrasi $50 \% \mathrm{a}_{3}=$ air kelapa konsentrasi $75 \%$. Faktor kedua MOL bonggol pisang terdiri dari 3 taraf perlakuan, yaitu: $\mathrm{m}_{0}=0 \mathrm{~mL} \operatorname{tanaman}^{-1} \mathrm{~m}_{1}=$ $40 \mathrm{~mL} \operatorname{tanaman}^{-1} \mathrm{~m}_{2}=80 \mathrm{~mL}$ tanaman $^{-1}$. Adapun parameter yang diamati diantaranya adalah tinggi tanaman (cm), jumlah daun (helai), jumlah anakan, dan jumlah umbi. Datadata penelitian yang telah didapat kemudian dianalisis secara statistik menggunakan analisis sidik ragam (ANOVA).

\section{Hasil dan Pembahasan}

\section{Tinggi Tanaman (cm)}

Berdasarkan Uji Lanjut Duncan taraf $5 \%$ didapati pengaruh signifikan pada perlakuan air kelapa $\mathrm{a}_{3}(75 \%)$ dan $\mathrm{m}_{1}\left(40 \mathrm{ml}_{\text {tanaman }}{ }^{-1}\right)$ terhadap tinggi tanaman $(\mathrm{cm})$ usia 3 - 4 MST. Perlakuan $a_{3} m_{1}$ memberikan rata-rata tinggi tanaman tertinggi dibandingkan dengan perlakuan kontrol dan taraf perlakuan lainnya (Tabel 1 dan 2). 
ISSN 2354-7251 (print)

Tabel 1. Interaksi pengaruh air kelapa dan MOL bonggol pisang terhadap tinggi tanaman bawang merah (cm) usia 3 MST

\begin{tabular}{cccc}
\hline \multirow{2}{*}{ Air Kelapa } & \multicolumn{3}{c}{ MOL Bonggol Pisang } \\
\cline { 2 - 4 } & Kontrol & 40 ml tanaman $^{-1}$ & 80 ml tanaman $^{-1}$ \\
\hline \multirow{2}{*}{ Kontrol } & $22,17 \mathrm{a}$ & $31,33 \mathrm{a}$ & $34,17 \mathrm{a}$ \\
& $\mathrm{A}$ & $\mathrm{B}$ & $\mathrm{B}$ \\
$25 \%$ & $28,83 \mathrm{~b}$ & $32,00 \mathrm{a}$ & $34,83 \mathrm{a}$ \\
& $\mathrm{A}$ & $\mathrm{AB}$ & $\mathrm{B}$ \\
$50 \%$ & $29,67 \mathrm{~b}$ & $30,67 \mathrm{a}$ & $30,33 \mathrm{a}$ \\
& $\mathrm{A}$ & $\mathrm{A}$ & $\mathrm{A}$ \\
$75 \%$ & $22,00 \mathrm{a}$ & $36,00 \mathrm{a}$ & $29,33 \mathrm{a}$ \\
& $\mathrm{A}$ & $\mathrm{C}$ & $\mathrm{B}$ \\
\hline
\end{tabular}

Keterangan: Angka rata-rata yang diikuti dengan huruf yang sama menunjukkan hasil yang berbeda tidak nyata menurut uji Duncan pada taraf $5 \%$ huruf kapital dibaca arah horizontal (baris) dan huruf kecil dibaca arah vertical (kolom)

Pada Tabel 1 didapati bahwa terdapat interaksi antara perlakuan air kelapa $a_{3}$ $(75 \%)$ terhadap perlakuan MOL bonggol pisang $\mathrm{m}_{1}\left(40 \mathrm{ml}\right.$ tanaman $\left.^{-1}\right)$ yang menunjukkan nilai signifikan tehadap tinggi tanaman bawang merah pada 3 MST sebesar $36,00 \mathrm{~cm}$ dibandingkan dengan tanaman kontrol yang memiliki rata-rata $22,17 \mathrm{~cm}$. Perlakuan air kelapa dengan konsentrasi $75 \%\left(\mathrm{a}_{3}\right)$ diduga mampu untuk membantu pertumbuhan awal tunas bawang merah karena di dalam air kelapa terkandung kandungan ZPT sitokinin yang memiliki fungsi sebagai zat yang dapat membantu dalam pembelahan sel serta meningkatkan metabolisme dan sintesis protein yang dapat merangsang untuk pertumbuhan tunas (Leovici et al., 2014).

Pada tanaman bawang merah dengan perbanyakan secara vegetatif, apabila telah muncul tunas maka pertumbuhannya akan cepat karena menurut Hamid \& Uniqbu (2016) setelah umbi bawang mucul tunas tanaman lebih cepat tumbuh karena tingginya nilai nisbah daun serta akar maka pertumbuhan tanaman jadi lebih cepat sehingga lebih cepat juga untuk membentuk organ tanaman yang baru. Selain itu, kandungan $\mathrm{P}$ yang ada pada air kelapa sebesar $13,17 \mathrm{mg} 100 \mathrm{~mL}^{-1}(0,013 \%)$ yang dikategorikan rendah berdasarkan standar mutu pupuk organik cair, namun diduga mampu untuk merangsang pertumbuhan akar diawal pertumbuhan dimana seperti yang dikatakan oleh Hardjowigeno (2015) fungsi $\mathrm{P}$ diantaranya berfungsi dalam pembentukan bunga, buah, dan biji, pembelahan sel, serta perkembangan akar. Sehingga tanaman yang diberi perlakuan dengan air kelapa $75 \%$ ini diduga terangsang pertumbuhan akarnya sehingga penyerapan unsur hara yang ada di media tanam terjadi lebih dahulu dan lebih baik dibandingkan dengan tanaman kontrol. Hal tersebut sejalan dengan apa yang dikatakan Prabowo \& Rachmawati (2020) yang menyatakan bahwa pertumbuhan akar yang maksimal akan meningkatkan penyerapan air supaya tekanan tugor juga dapat seimbang.

Pengaplikasian MOL bonggol pisang mampu mendukung pertumbuhan tanaman bawang merah karena $\mathrm{MOL}$ ini mensuplai kebutuhan hara $\mathrm{N}$ yang dapat mendukung pertumbuhan vegetatif awal. Diduga kandungan $\mathrm{N}$ yang ada dalam MOL bonggol pisang sebesar $0,14 \%$ mampu untuk membantu pertumbuhan tanaman bawang pada fase 
vegetatif awal diusia 3 dan 4 MST ini. Unsur hara $N$ dibutuhkan tanaman untuk pertumbuhan vegetatif, hal ini sejalan dengan Hardjowigeno (2015) yang berpendapat jika $\mathrm{N}$ adalah unsur hara essensial yang diperlukan dalam pertumbuhan awal atau pertumbuhan vegetatif tanaman.

Kedua faktor perlakuan saling berpengaruh dalam pembelahan sel pada tanaman dan akhirnya mempengaruhi pertumbuhan. Kandungan N MOL bonggol pisang yang lebih tinggi yaitu $0,14 \%$ dibandingkan dengan kandungan $N$ air kelapa yang hanya memiliki nilai sebesar $0,04 \%$ diduga dapat mensuplai kebutuhan $\mathrm{N}$ bagi tanaman bawang merah. Dari hasil Uji Lanjut Duncan taraf $5 \%$ juga didapati pengaruh yang signifikan pada taraf perlakuan $a_{3} m_{1}$ terhadap tinggi tanaman usia 4 MST dengan rata-rata sebesar 44,67 cm dibandingkan dengan kontrol yang memiliki tinggi rata-rata $35 \mathrm{~cm}$ (Tabel 2).

Tabel 2. Interaksi pengaruh air kelapa dan MOL bonggol pisang terhadap tinggi tanaman bawang merah $(\mathrm{cm})$ usia 4 MST

\begin{tabular}{cccc}
\hline \multirow{2}{*}{ Air Kelapa } & \multicolumn{3}{c}{ MOL Bonggol Pisang } \\
\cline { 2 - 4 } & Kontrol & $40 \mathrm{ml} \mathrm{tanaman}^{-1}$ & $80 \mathrm{ml} \mathrm{tanaman}^{-1}$ \\
\hline \multirow{2}{*}{ Kontrol } & $35 \mathrm{a}$ & $39,17 \mathrm{ab}$ & $41,83 \mathrm{~b}$ \\
& $\mathrm{~A}$ & $\mathrm{AB}$ & $\mathrm{B}$ \\
$25 \%$ & $39,5 \mathrm{a}$ & $37 \mathrm{a}$ & $43,5 \mathrm{~b}$ \\
& $\mathrm{AB}$ & $\mathrm{A}$ & $\mathrm{B}$ \\
$50 \%$ & $39,17 \mathrm{a}$ & $41,33 \mathrm{ab}$ & $35,67 \mathrm{ab}$ \\
& $\mathrm{AB}$ & $\mathrm{B}$ & $\mathrm{A}$ \\
$75 \%$ & $34,67 \mathrm{a}$ & $44,67 \mathrm{~b}$ & $40,33 \mathrm{ab}$ \\
& $\mathrm{A}$ & $\mathrm{B}$ & $\mathrm{B}$ \\
\hline
\end{tabular}

Keterangan: Angka rata-rata yang diikuti dengan huruf yang sama menunjukkan hasil yang berbeda tidak nyata menurut uji Duncan pada taraf $5 \%$ huruf kapital dibaca arah horizontal (baris) dan huruf kecil dibaca arah vertical (kolom)

Sementara itu, setelah 4 MST hasil analisis ragam menunjukkan tidak ada pengaruh yang signifikan baik interaksi maupun pengaruh mandiri dari faktor air kelapa dan MOL bonggol pisang pada tinggi tanaman 5-8 MST (Tabel 3).

Tabel 3. Pengaruh air kelapa dan MOL bonggol pisang terhadap tinggi tanaman ( $\mathrm{cm}$ ) bawang merah usia 5-8 MST

\begin{tabular}{ccccc}
\hline \multirow{2}{*}{ Perlakuan } & \multicolumn{4}{c}{ Rata - rata tinggi tanaman (cm) } \\
\cline { 2 - 5 } & $5 \mathrm{MST}$ & $6 \mathrm{MST}$ & $7 \mathrm{MST}$ & $8 \mathrm{MST}$ \\
\hline Air Kelapa & & & & \\
Kontrol & $42,1 \mathrm{a}$ & $48,4 \mathrm{a}$ & $50,17 \mathrm{a}$ & $48,94 \mathrm{a}$ \\
$25 \%$ & $46,8 \mathrm{a}$ & $48,7 \mathrm{a}$ & $49,24 \mathrm{a}$ & $49,50 \mathrm{a}$ \\
$50 \%$ & $46,5 \mathrm{a}$ & $49,5 \mathrm{a}$ & $49,11 \mathrm{a}$ & $48,08 \mathrm{a}$ \\
$75 \%$ & $46,6 \mathrm{a}$ & $46,6 \mathrm{a}$ & $50,94 \mathrm{a}$ & $48,78 \mathrm{a}$ \\
\hline MOL Bonggol Pisang & & & & \\
Kontrol & $44,7 \mathrm{a}$ & $49,2 \mathrm{a}$ & $49,4 \mathrm{a}$ & $48,00 \mathrm{a}$ \\
40 ml tanaman $^{-1}$ & $46,6 \mathrm{a}$ & $49,4 \mathrm{a}$ & $49,14 \mathrm{a}$ & $47,22 \mathrm{a}$ \\
80 ml tanaman $^{-1}$ & $45,3 \mathrm{a}$ & $49,9 \mathrm{a}$ & $51,06 \mathrm{a}$ & $51,26 \mathrm{a}$ \\
\hline
\end{tabular}

Keterangan: Angka rata-rata yang diikuti dengan huruf yang sama menunjukkan tidak berbeda nyata berdasarkan uji F $5 \%$

Pada Tabel 3 terlihat bahwa kedua faktor perlakuan menunjukkan tidak adanya pengaruh signifikan. Diduga faktor pertama yang menyebabkan tidak adanya pengaruh pada tinggi tanaman $(\mathrm{cm})$ bawang merah pada usia 5-8 MST ini adalah karena ZPT 
sitokinin dari air kelapa hanya berpengaruh pada fase vegetatif awal yaitu 3 dan 4 MST ketika fitohormon (hormone alami) tanaman bawang merah masih rendah, hal tersebut karena bibit umbi bawang yang digunakan baru melalui masa penyimpanan selama 2 bulan, sementara menurut Sumarni \& Hidayat (2010) umbi yang digunaka sebagai bibit biasanya memakan waktu penyimpanan selama 2-4 bulan yang ditandai dengan ciri tunas sudah muncul pada ujung umbi, hal tersebut secara tidak langsung menandakan bahwa fitohormon di dalam bibit sudah terpenuhi karena sudah siap untuk dilakukan penanaman.

Pada usia 5-8 MST diduga keadaan fitohormon yang terdapat didalam tanaman bawang merah sudah cukup untuk membantu pertumbuhan tanaman tersebut sehingga faktor air kelapa tidak memberikan pengaruh signifikan pada tinggi tanaman (cm). Leovici et al., (2014) menjelaskan bahwa penggunaan hormon tumbuhan eksogen dalam hal ini adalah ZPT sitokinin yang dihasilkan oleh air kelapa hanya mampu memberikan pengaruh terhadap tanaman apabila hormon yang ada di jaringan tanaman belum cukup. Hal tersebut diperkuat dengan penelitiannya yang menunjukan bahwa hasil tinggi tanaman tebu yang diberi perlakuan konsentrasi air kelapa sebesar 50\% menunjukan hasil yang nyata pada $40 \mathrm{HST}$, namun tidak berbeda nyata pada usia $80 \mathrm{HST}$ dan $120 \mathrm{HST}$ pada tinggi tanaman tebu.

Faktor kedua adalah dari hasil analisis MOL bonggol pisang yang memiliki kandungan hara yang masih dibawah rata-rata standar mutu pupuk organik cair menyebabkan tidak memberikan pengaruh signifikan pada tinggi tanaman usia 5-8 MST. Hal ini karena diduga semakin besar tanaman maka hara yang dibutuhkan semakin banyak. Kurnianingsih et al., (2018) berpendapat apabila kebutuhan hara suatu tanaman dapat terpenuhi, proses metabolisme di dalam tanaman akan berjalan secara baik juga.

Seiring dengan bertambahnya usia suatu tanaman hara yang dibutuhkan juga semakin banyak dan harus terpenuhi. Namun disisi lain diduga terdapat pengaruh dari faktor waktu simpan MOL bonggol pisang selama 6 minggu waktu aplikasi yang mempengaruhi kualitas kandungan didalamnya seperti unsur hara makro dan mikro, mikroba, atau pun C-organik dan C/N rasio. Penelitian Budiyani et al., (2016) mengenai waktu fermentasi pembuatan MOL bonggol pisang yaitu selama 2 minggu, 4 minggu, dan 6 minggu menunjukkan hasil analisis statistik bahwa rata-rata kandungan $\mathrm{N}$-total menurun dari $0,020 \%, 0,017 \%$, dan 0,012\% secara berurutan. Begitu juga dengan kandungan $\mathrm{P}$ tersedia menurun sebesar $511,30 \mathrm{mg} \mathrm{kg}^{-1}, 443,20 \mathrm{mg} \mathrm{kg}^{-1}$, dan 430,82 $\mathrm{mg} \mathrm{kg}^{-1}$ secara berurutan, serta kandungan C-Organik yang menunjukkan penurunan sebesar 2,96\%, 2,90\%, dan 2,77 \% secara berurutan serta C/N Rasio 232,73, 217,73, dan 194,86 secara berurutan. 
Hasil analisis kadungan MOL bonggol pisang pada penelitian kali ini memberikan hasil bahwa kandungan Karbon (C-organik) sebesar 1,42\% dimana masih dibawah standar mutu yang seharusnya menunjukkan nilai $6 \%$ serta kandungan Nitrogen $(\mathrm{N})$ yang dimiliki menunjukan hasil yang rendah yaitu hanya berkisar $0,14 \%$ dimana masih dibawah standar pupuk organik cair yang seharusnya memiliki mutu kandungan $\mathrm{N}$ berkisar 3-6\%, hal tersebut diduga selain dapat menyebabkan ketersediaan hara untuk tanaman yang kurang optimal dan tidak tersedia, hal lain yang dapat diduga adalah dapat menyebabkan total populasi mikroorganisme tidak banyak didapati dengan ketersediaan unsur $\mathrm{N}$ yang tidak optimal karena mikroorganisme bisa tumbuh dalam waktu yang cepat apabila unsur karbon dan nitrogen terpenuhi (Budiyani et al., 2016), karena kandungan C-organik memiliki peran sebagai energi dan $\mathrm{N}$ digunakan mikroorganisme untuk sintesis protein. Hal tersebut dapat membuat keberadaan populasi bakteri-bakteri potensial untuk merombak bahan organik rendah dan perombakan didalamnya tidak dapat berjalan secara optimal juga.

Data pada Tabel 6 menunjukkan adanya penurunan angka rata-rata pada beberapa perlakuan menurun pada $8 \mathrm{MST}$, hal tersebut disebabkan oleh beberapa faktor, faktor pertama adalah pengendalian hama ulat grayak yang dilakukan secara mekanik yaitu dengan mengambil ulat dan membuangnya jauh dari area pertanaman pada minggu sebelumnya tidak terlalu berpengaruh dan dirasa kurang efektif untuk penurunan serangan hama sehingga menyebabkan tinggi tanaman menjadi berkurang pada beberapa perlakuan. Faktor yang kedua adalah pada usia 8 MST atau 56 HST ini menurut Pusat Penelitian dan Pengembangan Hortikultura (2020) sudah memasuki fase pematangan umbi bukan lagi fase vegetatif. Hal tersebut sejalan dengan pendapat Fatmawaty et al., (2015) yang menyatakan, umur pemanenan tanaman bawang merah yang dimulai sejak 60 HST atau apabila dikalkulasikan berkisar antara 8 sampai 9 MST itu tidak akan mengalami pertumbuhan dan juga penurunan atau konstan.

\section{Jumlah Daun (helai)}

Hasil analisis ragam menunjukkan bahwa faktor air kelapa dan MOL bonggol pisang tidak menunjukkan hasil yang signifikan baik secara interaksi ataupun pengaruh mandiri pada rata-rata jumlah daun (helai) tanaman bawang merah usia 3 MST-8 MST (Tabel 4). 
Tabel 4. Pengaruh air kelapa dan MOL bonggol pisang terhadap jumlah daun (helai) bawang merah usia $3-8$ MST

\begin{tabular}{|c|c|c|c|c|c|c|}
\hline \multirow[t]{2}{*}{ Perlakuan } & \multicolumn{6}{|c|}{ Rata - rata jumlah daun (helai) } \\
\hline & $3 \mathrm{MST}$ & $4 \mathrm{MST}$ & $5 \mathrm{MST}$ & $6 \mathrm{MST}$ & $7 \mathrm{MST}$ & $8 \mathrm{MST}$ \\
\hline \multicolumn{7}{|l|}{ Air Kelapa } \\
\hline Kontrol & $11,78 \mathrm{a}$ & $16,10 \mathrm{a}$ & $22,33 \mathrm{a}$ & $29,22 \mathrm{a}$ & $28,00 \mathrm{a}$ & $26,44 \mathrm{a}$ \\
\hline $25 \%$ & $12,89 \mathrm{a}$ & $17,10 \mathrm{a}$ & $23,44 \mathrm{a}$ & $29,44 \mathrm{a}$ & $32,00 \mathrm{a}$ & $32,00 \mathrm{a}$ \\
\hline $50 \%$ & 9,78 a & $13,00 \mathrm{a}$ & $17,00 \mathrm{a}$ & $23,11 \mathrm{a}$ & $23,67 \mathrm{a}$ & $23,67 \mathrm{a}$ \\
\hline $75 \%$ & $10,33 \mathrm{a}$ & $14,10 \mathrm{a}$ & $19,44 \mathrm{a}$ & $26,78 \mathrm{a}$ & $25,44 \mathrm{a}$ & $23,22 \mathrm{a}$ \\
\hline \multicolumn{7}{|c|}{ MOL Bonggol Pisang } \\
\hline Kontrol & $10,33 \mathrm{a}$ & $15,17 \mathrm{a}$ & $21,08 \mathrm{a}$ & $28,08 \mathrm{a}$ & $27,42 \mathrm{a}$ & $26,25 \mathrm{a}$ \\
\hline $40 \mathrm{ml}$ tanaman $^{-1}$ & $12,42 \mathrm{a}$ & $15,83 \mathrm{a}$ & $21,25 \mathrm{a}$ & $27,58 \mathrm{a}$ & $28,50 \mathrm{a}$ & $27,17 \mathrm{a}$ \\
\hline $80 \mathrm{ml}_{\text {tanaman }}^{-1}$ & $10,83 \mathrm{a}$ & $14,25 \mathrm{a}$ & $19,33 \mathrm{a}$ & 25,75 a & 25,92 a & $25,58 \mathrm{a}$ \\
\hline
\end{tabular}

Dari Tabel 4 diketahui kedua perlakuan air kelapa dan MOL bonggol pisang tidak memberikan pengaruh yang nyata terhadap jumlah daun tanaman bawang merah. Menurut Latarang \& Syakut (2006) jumlah daun tanaman yang terbentuk akan ditentukan oleh banyaknya sel serta ukuran sel didalam jaringan tanaman, selain itu faktor hara tersedia dan yang dapat diserap oleh akar bisa mempengaruhi tanaman karena dimanfaatkan untuk cadangan makanan, dalam kata lain pembentukan jumlah daun dipengaruhi oleh faktor internal dan eksternal.

Kandungan $\mathrm{N}$ pada kedua faktor perlakuan yaitu air kelapa dan MOL bonggol pisang masih dibawah standar mutu pupuk organik cair yaitu 0,04\% untuk air kelapa dan 0,14\% untuk MOL bonggol pisang begitu juga dengan kandungan $\mathrm{P}$ yang menunjukkan nilai $0,043 \%$ dan $0,013 \%$, kandungan tersebut masih dibawah mutu pupuk organik cair yang dimana memiliki standar berkisar 3 hingga 6\% sehingga tidak dapat mensuplai tanaman agar pertumbuhannya optimal. Padahal menurut Latarang \& Syakut (2006) N berperan sebagai bahan penyusun enzim serta molekul klorofil dan $\mathrm{P}$ yang memiliki peran didalam transfer energi pada sel tanaman. Hal tersebut akan berkaitan dengan fotosintat, seiring dengan adanya peningkatan klorofil maka hasil fotosintesis berupa fotosintat akan terbentuk lebih besar seta dapat membantu dalam proses pembelahan sel yang selanjutnya akan menambah organ tanaman baru.

Jumlah rata-rata daun belum sesuai dengan deskripsi tanaman, terlepas dari faktor utama perlakuan yang diberikan yaitu air kelapa dan MOL bonggol pisang sebenarnya daun terbentuk dipengaruhi oleh beberapa faktor. Fatmawaty et al., (2015) mengemukakan bahwa pembentukan daun pada tanaman dipengaruhi oleh faktor internal yaitu genetik dari tanaman itu sendiri, tetapi faktor eksternal yaitu lingkungan yang mendukung dapat membantu untuk mempercepat pembentukan daun.

Faktor lingkungan yang menyebabkan tidak adanya pengaruh adalah faktor kelembaban udara yang cukup rendah untuk pertumbuhan bawang di tempat penelitian yaitu mencapai kelembaban terendah $72 \%$. Lestari (2019) berpendapat bahwa 
kelembaban yang rendah bisa memberikan pengaruh terhadap proses fotosintesis, dan kelembaban udara yang rendah bisa memberikan pengaruh terhadap keseimbangan air didalam tanah atau pun tanaman. Apabila kelembaban udara optimal hasil fotosintat bisa dialirkan ke bagian pucuk dan meningkatkan pertumbuhan daun.

\section{Jumlah Anakan}

Hasil analisis ragam menunjukkan tidak adanya pengaruh signifikan baik secara interaksi atau pun mandiri dari perlakuan air kelapa dan MOL bonggol pisang terhadap jumlah anakan tanaman bawang merah (Tabel 5).

Tabel 5. Pengaruh air kelapa dan MOL bonggol pisang terhadap jumlah anakan bawang merah usia 3-8 MST

\begin{tabular}{|c|c|c|c|c|c|c|}
\hline \multirow{2}{*}{ Perlakuan } & \multicolumn{6}{|c|}{ Rata - rata jumlah anakan } \\
\hline & $3 \mathrm{MST}$ & $4 \mathrm{MST}$ & $5 \mathrm{MST}$ & $6 \mathrm{MST}$ & $7 \mathrm{MST}$ & $8 \mathrm{MST}$ \\
\hline \multicolumn{7}{|l|}{ Air Kelapa } \\
\hline Kontrol & $3,1 \mathrm{a}$ & $3,7 \mathrm{a}$ & $3,8 \mathrm{a}$ & $3,9 \mathrm{a}$ & $3,9 \mathrm{a}$ & 3,9 a \\
\hline $25 \%$ & 2,91 & $3,4 \mathrm{a}$ & $4,0 \mathrm{a}$ & $4,0 \mathrm{a}$ & $4,0 \mathrm{a}$ & $4,0 \mathrm{a}$ \\
\hline $50 \%$ & $2,3 \mathrm{a}$ & $2,6 \mathrm{a}$ & $2,8 \mathrm{a}$ & $2,9 \mathrm{a}$ & $2,9 \mathrm{a}$ & $2,9 \mathrm{a}$ \\
\hline $75 \%$ & $2,6 \mathrm{a}$ & $2,8 \mathrm{a}$ & $3,6 \mathrm{a}$ & $3,6 \mathrm{a}$ & $3,6 \mathrm{a}$ & $3,6 \mathrm{a}$ \\
\hline \multicolumn{7}{|l|}{ Mol Bonggol Pisang } \\
\hline Kontrol & $2,7 \mathrm{a}$ & $3,3 \mathrm{a}$ & $3,8 \mathrm{a}$ & $3,8 \mathrm{a}$ & $3,8 \mathrm{a}$ & $3,8 \mathrm{a}$ \\
\hline $40 \mathrm{ml}^{\text {tanaman }}-1$ & $3,0 \mathrm{a}$ & $3,2 \mathrm{a}$ & $3,6 \mathrm{a}$ & $3,6 \mathrm{a}$ & $3,6 \mathrm{a}$ & $3,6 \mathrm{a}$ \\
\hline $80 \mathrm{ml}$ tanaman $^{-1}$ & $2,5 \mathrm{a}$ & $2,9 \mathrm{a}$ & $3,2 \mathrm{a}$ & $3,3 \mathrm{a}$ & 3,3 a & $3,3 \mathrm{a}$ \\
\hline
\end{tabular}

Hasil analisis ragam tidak menunjukkan adanya hasil yang signifikan baik secara interaksi ataupun pengaruh mandiri dari faktor perlakuan air kelapa dan MOL bonggol pisang. Bahkan apabila dilihat dari rata-rata tanaman kontrol memiliki rata-rata anakan yang cenderung sama dibandingkan dengan tanaman yang diberi faktor perlakuan air kelapa dan MOL bonggol pisang. Pada penelitian kali ini hasil analisis air kelapa dan MOL bonggol pisang menunjukkan hasil kandungan $\mathrm{N}$ yang masih dibawah standar mutu pupuk organik cair yaitu $0,14 \%$ dan $0,04 \%$ tidak efektif untuk membantu pertumbuhan jumlah anakan tanaman bawang merah. Faktor eksternal seperti ketersediaan hara $\mathrm{N}$ berperan cukup penting untuk pertumbuhan vegetatif, $\mathrm{N}$ adalah hara makro dimana jumlahnya banyak diperlukan dalam proses pertumbuhan tanaman bersamaan dengan unsur hara makro lainnya yaitu $\mathrm{P}$ dan $\mathrm{K}$. Namun $\mathrm{N}$ ini lah yang memiliki peran utama dalam pertumbuhan vegetatif tanaman, seperti halnya dalam laju pertumbuhan dimana dapat meningkatkan sintesa protein yang kemudian protein tersebut digunakan dalam pembentukan sel tanaman, maka apabila jika kandungan $\mathrm{N}$ optimal maka akan mampu untuk membantu laju pertumbuhan (Anisyah et al., 2014).

Hal lainnya yang menyebabkan rata-rata jumlah anakan tidak menunjukkan hasil yang signifikan adalah karena diduga oleh faktor internal dalam tanaman bawang merah sendiri. Sebagaimana Simanjuntak et al., (2013) berpendapat bahwa banyaknya jumlah anakan yang terbentuk pada tanaman bawang merah pada umumnya dihasilkan oleh sifat 
ISSN 2354-7251 (print)

genetis yang terdapat pada tanaman dan tidak mudah dirubah oleh faktor luar. Hal itu diperkuat oleh penelitian Anisyah et al., (2014) mengenai respons tanaman bawang merah dengan berbagai macam bahan organik menunjukkan hasil rata-rata anakan bawang merah yang menunjukkan bahwa tanaman kontrol memiliki rata-rata yang tidak signifikan dengan tanaman lain, dimana perlakuan kontrol memiliki rata-rata jumlah anakan sebanyak 6,28 dan jumlah anakan terbanyak ada pada perlakuan bahan organik vermikompos sebesar 6,48 namun tidak menunjukkan hasil yang signifikan.

\section{Jumlah Umbi}

Hasil uji analisis ragam dapat dilihat pada Tabel 6. Menunjukkan bahwa hasil analisis ragam menunjukkan hasil yang tidak signifikan baik secara interaksi atau pun mandiri dari masing-masing perlakuan, baik air kelapa atau pun MOL bonggol pisang.

Tabel 6. Pengaruh air kelapa dan MOL bonggol pisang terhadap jumlah umbi bawang merah

\begin{tabular}{cc}
\hline Perlakuan & Rata - rata jumlah umbi \\
\hline Air Kelapa & \\
Kontrol & $3,9 \mathrm{a}$ \\
$25 \%$ & $4,0 \mathrm{a}$ \\
$50 \%$ & $2,9 \mathrm{a}$ \\
$75 \%$ & $3,6 \mathrm{a}$ \\
\hline Mol Bonggol Pisang & \\
Kontrol $^{-1}$ & $3,8 \mathrm{a}$ \\
80 ml tanaman $^{-1}$ & $3,6 \mathrm{a}$ \\
80 ml tanaman $^{-1}$ & $3,3 \mathrm{a}$ \\
\hline
\end{tabular}

Keterangan: Angka rata-rata yang diikuti dengan huruf yang sama menunjukkan tidak berbeda nyata berdasarkan uji F 5\%

Pada Tabel 6 menunjukkan bahwa faktor air kelapa dan MOL bonggol pisang tidak menunjukkan hasil yang signifikan terhadap semua tanaman pengamatan. Ada pun pengaruh tertinggi diberikan oleh perlakuan air kelapa dengan konsentrasi $25 \%$ yaitu memiliki rata-rata sebanyak 4 umbi namun tidak berbeda nyata dengan kontrol yang memiliki rata-rata 3,9 umbi atau pun dengan perlakuan lainnya. Begitu pula dengan faktor MOL bonggol pisang yang tidak berpengaruh nyata, dan bahkan kontrol yang memiliki rata-rata terbanyak dibanding perlakuan lainnya yaitu 3,8 umbi.

Rata-rata jumlah umbi pada penelitian kali ini sudah sesuai dengan deskripsi tanaman yaitu berjumlah 2-5 per rumpun. Jumlah umbi ditentukan oleh banyaknya anakan yang terbentuk, seperti halnya jumlah anakan, menurut Azmi et al., (2016) karakter jumlah umbi bawang yang terbentuk banyak dipengaruhi oleh faktor internal dan sedikit sekali yang dipengaruhi oleh faktor eksternal atau lingkungan. Hal ini sejalan dengan penelitian Nurman et al., (2017) yang menunjukkan bahwa air kelapa serta POC limbah cair tahu, secara mandiri faktor air kelapa tidak signifikan pada jumlah umbi bawang merah. Hal tersebut menurutnya karena setiap tanaman memiliki respon yang berbeda karena dipengaruhi oleh faktor internal dan kepekaan suatu jaringan. 
Penelitian lainnya yang dilakukan oleh Azmi et al., (2016) dimana penelitian tersebut dilakukan dengan menggunakan 3 varietas tanaman bawang merah berbeda yaitu diantaranya varietas Bima, Maja, dan Sumenep. Hasil yang didapat adalah jumlah umbi varietas Bima tersebut mencapai rata-rata 11,73 umbi yang dimana angka tersebut mendekati potensi maksimum yang pada umumnya umbi varietas Bima dapat menghasilkan umbi sebanyak yaitu beriksar 7-12 umbi per tanaman. Hal itu menunjukkan jika faktor eksternal berupa air kelapa dan MOL bonggol pisang memang kurang efektif untuk mempengaruhi jumlah umbi bawang merah karena bahwasannya faktor internal atau genetik lah yang lebih berperan dalam penentu jumlah umbi bawang merah.

\section{$4 \quad$ Kesimpulan}

Terjadi pengaruh signifikan antara air kelapa dan MOL bonggol pisang pada tinggi tanaman bawang merah (Allium ascalonicum L.) diusia 3 MST dan 4 MST dan tidak berpengaruh secara signifikan pada parameter pengamatan lainnya seperti jumlah daun, jumlah anakan, dan jumlah umbi bawang merah hingga akhir pengamatan baik secara interaksi atau pun secara mandiri. Namun, tidak didapati konsentrasi air kelapa atau pun dosis MOL bonggol pisang yang tepat untuk pertumbuhan tanaman bawang merah (Allium ascalonicum L.). Penulis menyarankan untuk memperhatikan kelembaban udara pada lingkungan tumbuh dan juga untuk memperhatikan waktu simpan MOL bonggol pisang karena dapat mempengaruhi kandungan hara didalamnya.

\section{Daftar Pustaka}

Aini, D. N., Sugiyanto, B., \& Herlinawati. (2017). Aplikasi Mikroorganisme Lokal Bonggol Pisang dan Pupuk Kandang Kambing Terhadap Produksi Kedelai ( Glycine max L. Merrill) Var. Baluran. Agripima, Journal of Applied Agricultural Sciences, 1(1), 33-40. https://doi.org/10.25047/agriprima.v1i1.13

Anisyah, F., Sipayung, R., \& Hanum, C. (2014). Pertumbuhan dan Produksi Bawang Merah dengan Pemberian Berbagai Pupuk Organik. Jurnal Online Agroekoteknologi, 2(2), 482-496.

Ardi, D. T., Haryati, \& Ginting, J. (2018). Pemberian KNO3 dan Air Kelapa pada Uji Viabilitas Benih Pepaya (Carica Papaya L). Jurnal Agroteknologi FP USU, 6(4), 730737. https://doi.org/10.1017/CBO9781107415324.004

Azmi, C., Hidayat, I. M., \& Wiguna, G. (2016). Pengaruh Varietas dan Ukuran Umbi terhadap Produktivitas Bawang Merah. Jurnal Hortikultura, 21(3), 206-213. https://doi.org/10.21082/jhort.v21n3.2011.p206-213

Budiyani, N. K., Soniari, N. N., \& Sutari, N. W. (2016). Analisis Kualitas Larutan Mikroorganisme Lokal (MOL) Bonggol Pisang. E-Jurnal Agroekoteknologi Tropika (Journal of Tropical Agroecotechnology), 5(1), 63-72. http://ojs.unud.ac.id/index.php/JAT 
Duaja, W. (2012). Pengaruh Pupuk Urea, Pupuk Organik Padat dan Cair Kotoran Ayam terhadap Sifat Tanah, Pertumbuhan dan Hasil Selada Keriting di Tanah Inceptisol. Journal Online Universitas Jambi Bioplantae, 1(4), 236-246. online-journal.unja.ac.id

Fatmawaty, A. A., Ritawati, S., \& Said, L. N. (2015). Pengaruh Pemotongan Umbi Dan Pemberian Beberapa Dosis Pupuk NPK Majemuk Terhadap Pertumbuhan dan Hasil Tanaman Bawang Merah (Allium ascolanicum L.). Agrologia Jurnal IImu Budidaya Tanaman, 4(2), 69-77. https://doi.org/10.30598/a.v4i2.201

Hamid, I., \& Uniqbu, D. F. (2016). Pertumbuhan dan Produksi Bawang Merah (Allium ascalonicum L.) pada Perlakuan Pemotongan Umbi dan Berbagai Takaran Bokashi Pupuk Kandang Ayam di Desa Waefusi Kecamatan Namrole Kab. Buru Selatan. Jurnal IImiah Agribisnis Dan Perikanan, 9(2).

Hardjowigeno, S. (2015). Ilmu Tanah. Jakarta: Akademi Pressindo

Kurnianingsih, A., Susilawati, \& Sefrila, M. (2018). Karakter Pertumbuhan Tanaman Bawang Merah Pada Berbagai Komposisi Media Tanam. Jurnal Hortikultura Indonesia, 9(3), 167-173. https://doi.org/10.29244/jhi.9.3.167-173

Latarang, B., \& Syakut, A. (2006). Pertumbuhan dan Hasil Bawang Merah (Allium ascalonicum L.) pada Berbagai Dosis Pupuk Kandang. J. Agroland, 13(3), 265-269.

Leovici, H., Kastono, D., \& Putra, E. T. (2014). Pengaruh Macam dan Konsentrasi Bahan Organik Sumber Zat Pengatur Tumbuh Alami terhadap Pertumbuhan Awal Tebu (Saccharum officinarum L.). Vegetalika, 3(1), 22-34. https://doi.org/10.1007/springerreference_69332

Lestari, Sumarsono, \& Sutarno. (2019). Respon Pertumbuhan dan Produksi Bawang Merah (Allium ascalonicum L.) terhadap Frekuensi dan Level Mikroorganisme Lokal Bonggol Pisang. Jurnal Agro Complex, 3(3), 105-113. http://ejournal2.undip.ac.id/index.php./joac

Napitupulu, B. S., Lahay, R. R., \& Barus, A. (2018). Pengaruh Konsentrasi Air Kelapa dan Lama Perendaman terhadap Pertumbuhan dan Produksi Bawang Merah Varietas Tuk Tuk (Allium ascaloicum L.) Asal Biji. Jurnal Agroekoteknologi FP USU, 6(4), 902-907. https://doi.org/https://jurnal.usu.ac.id/agroekoteknologi

Nizar, A. (2018). Pengaruh Penggunaan Rebung Bambu Sebagai Zat Pengatur Tumbuh Terhadap Pertumbuhan dan Produksi Bawang Merah (Allium ascolonicum L.) Varietas Lokal Bauji. Jurnal Agriekstensia, 17(2), 92-98.

Nurman, Zuhry, E., \& Dini, I. R. (2017). Pemanfaatan ZPT air kelapa dan POC limbah cair tahu untuk pertumbuhan dan produksi bawang merah (Allium ascalonicum $L$.). Jom Faperta, 4(2), 1-15.

Prabowo, I., \& Rachmawati, D. (2020). Respon Fisiologis dan Anatomi Akar Tanaman Bayam (Amaranthus tricolor L.) terhadap Cekaman $\mathrm{NaCl}$. Jurnal Penelitian Saintek, 25(1), 36-43. https://doi.org/10.21831/jps.v25i1.27357

Pusat Data dan Sistem Informasi Pertanian. (2018). Statistik Pertanian 2018 (Agricultural Statistics). Kementerian Pertanian Republik Indonesia.

Ramadhani, F., Kurniastuti, T., \& Puspitorini, P. (2019). Pengaruh Lama Perendaman Air Kelapa terhadap Pertumbuhan dan Hasil Tanaman Bawang Merah (Allium ascalonicum L.) pada Berbagai Macam Media. Jurnal Viabel Pertanian, 6(1), 33-44. http://ejournal.uniisbablitar.ac.id/index.php/viabel

Roeswitawati, D., \& Huda, M. M. (2018). Effect of Local Microorganism (Banana Hump Waste) Dosage to Varieties of Mustard Crops (Brassica sinensis L.). Journal of $\begin{array}{llll}\text { International Scientific } & \text { Publications, } & 63 .\end{array}$ https://doi.org/10.1017/CBO9781107415324.004 
Roeswitawati, D., Ningsih, Y. U., \& Muhidin. (2018). The Effect of Local Microorganism (MOL) Concentration of Banana Hump and Fruit Waste on the Growth and Yield of Broccoli Plants (Brassica oleracea). Advances in Engineering Research, 172, 310314. https://doi.org/10.2991/fanres-18.2018.62

Siburian, E., \& Luthfi, A. M. S. (2019). Uji Berbagai Bahan Alami sebagai Sumber Zat Pengatur Tumbuh dalam Meningkatkan Viabilitas Benih True Seed Shallot Bawang Merah. Jurnal Pertanian Tropik, 6(1), 80-87. https://jurnal.usu.ac.id/index.php/Tropik

Simanjuntak, A., Lahay, R., \& Purba, E. (2013). Respon Pertumbuhan dan Produksi Bawang Merah (Allium ascalonicum) terhadap Pemberian Pupuk NPK dan Kompos Kulit Buah Kopi. Jurnal Online Agroekoteknologi, 1(3), 362-373.

Simatupang, S., Sipahutar, T., \& Sutanto, A. N. (2017). Kajian Usahatani Bawang Merah Dengan Paket Teknologi Good Agriculture Practices. Jurnal Pengkajian Dan $\begin{array}{llll}\text { Pengembangan Teknologi } & \text { Pertanian, }\end{array}$ https://doi.org/10.21082/jpptp.v20n1.2017.p13-24

Sumarni, N., \& Hidayat, A. (2005). Budidaya Bawang Merah. In Balitsa. Balai Penelitian Tanaman Sayuran. http://balitsa.litbang.pertanian.go.id

Triyanto, Y., \& Maharani, S. (2019). Program Pengabdian Masyarakat Melalui Program Pembuatan Pupuk Organik Cair (POC) dari Bonggol Pisang. Jurnal Pengabdian Masyarakat, 1(1), 10-17. https://doi.org/10.1017/CBO9781107415324.004 